\title{
Case-study based development of professional communicative competence of agricultural and environmental engineering students
}

\author{
Irina Oblova ${ }^{1,{ }^{*}}$, Irina Gerasimova $^{1}$, and Julia Sishchuk $^{1}$ \\ ${ }^{1}$ Saint Petersburg Mining University, 2, $21^{\text {st }}$ Line, 199106 St. Petersburg, Russia
}

\begin{abstract}
This article demonstrates the effectiveness of employing the case study method to teach English as a foreign language to the agricultural and environmental engineering students. It should be useful to those who are trying to contribute to the development of the technology relevant to the contemporary educational challenges based on the unity of applied and theoretical aspects of teaching English within a perspective of developing students' environmental responsibility. This research includes three-year study conducted both in the institution of higher professional education and in one of the largest concentrating enterprise sharing strong environmental ethics in Russia from 2017 to 2019. The research methodology includes: analysis of literature on the main purposes of the engineering training as well as environmental concerns; the analysis of the ways of teaching case study; an assessment of purposes, needs and functions for which English is required. The findings of this research are as follows: firstly, engineering student's professional communicative competence is effectively developed within a case study analysis based on real cases from current companies. Secondly, students are more satisfied with their English course and more willing to put their English to practical use when foreign language skills and their professional engineering issues are brought together.
\end{abstract}

\section{Introduction}

The projected excessive demand for skilled occupations in industry and agriculture undoubtedly suggests the need for highly qualified specialists able to interact with counterparts worldwide on a professional basis in foreign languages. At present English is necessary to be employed, get promoted and perform professional duties to the highest standards. Consequently, there is an urgent need for the technology relevant to contemporary needs in education based on the unity of theoretical and practice-oriented forms of learning.

This demand has generated a linguistic branch within the field of English language teaching, namely, English for Specific Purposes. With the increasing role that technology plays in academic life in general, development of professional competence of the agricultural and environmental engineering students is inevitable.

* Corresponding author: GolovinaMA@yandex.ru 
The present research aims at improving understanding of which technology is more efficient within teaching future engineers who learn foreign languages more likely in order to perform job-related functions than to study grammar and language structures. Here we can formulate a hypothesis of our research: is there such a thing as an ideal method in teaching English to university students with reference to their occupation or profession? Or are any techniques more appropriate for the students of agriculture and environmental engineering fields of study than others? The paper suggests the ways of employing case study method which allows joint study of the English language context with integrating into subject matter area important to students who pursue careers as to develop their professional communicative competence. Moreover, for the better understanding of how English for Specific Purposes can contribute to meeting future specialists' occupational needs the ways of delivering more relevant market-oriented meaningful ESP course content are worth analysing.

\section{Literature review}

The analysis of literature on both the main purposes and environmental aspects of the engineering education is to be taken to bring coherence to the students' occupational needs and ESP curriculum development. Although the literature on ESP course development presents it in variety of contexts, more inclusive account of the process is to be fostered. There has been much discussion among ESP specialists on the development of professional and communicative competence of students [1-4].

One of the effective communicative methods that allows considering a foreign language not so much as a matter of study but mainly as a tool for teaching environmental engineering disciplines is case studies. Being introduced into social sciences by Frederic Le Play in 1829 the case-study method turned out to gain its popularity in foreign language teaching thanks to its capacity for development of students' linguistic competences, academic and communicative skills [5]. As founders of the case method A. Hornby, H. Palmer and M. West based it on rigorous selection of lexical material in the early 20th century. This method was popularized within English for Specific purpose course in 1967 when Strauss and Glazer created their ground theory [6].

Defining this approach as a student oriented active training based on solving problem situations most scholars referred it to non-gaming simulation used to explore, to propose hypotheses, to describe, to justify, to validate and utilize knowledge [7-9]. Case study has been explored by three investigators in particular, Merriam [10], Yin [11-17], and Stake [1822].

According to Merriam, (1998) case study is intended for an in-depth focus on the cases while retaining a holistic and real-world perspective since a case is studied as a whole, in its entirety (Stake, 2005), concentrating on many, if not all, the variables present in a single unit (Merriam, 1988). It includes as many variables as possible and offers a portrayal of the dynamic interactions among significant factors characteristic of the phenomenon. The theme of case studies runs through all the publications of Yin over the years, providing great support of how integration of case studies with quantitative methods has contributed to the development of scientific research in general. This method has its peculiar advantages and disadvantages, depending upon three conditions: the type of research issue, the control an investigator has over actual behavioral events and the focus on contemporary as opposed to historical phenomena (Yin, 2015). In general, case studies are the preferred method when how and why questions are being posed, the investigator has little control over events, and the focus is on a contemporary phenomenon within a real-life context.

The importance of numerous contributions of the scholars, teachers, policy-makers and researchers from Europe and the USA made to develop this method cannot be overwhelmed. For example, in the study by Daly [23], the classification of cases was made for different 
types of learners and teachers. Referring to a case as an empirical inquiry Yin (1981, 1994, 2005, 2009, 2015) surveyed its development over a period of years and provided guidelines for its advancement. From his research, it seems clear that the case- study is a contemporary phenomenon within its real-life context, especially when the boundaries between phenomenon and context are not clearly evident.

At present American and European case-study schools are known to coexist. The first school goal is to teach students how to find the only right solution; the second one advocates variety of alternatives [24].

Much research on case studies has been done in the Russian Federation since late 70s of the 20th century. The issue of case approach has been studied by Galskova, Tsareva and others scholars [25-27]. Several studies suggest that the case study approach is focused on the development of students' key professional competencies, such as the ability to analyze a large amount of information and make decisions and achieve language proficiency [28-30]. In their works some specific requirements to the contextual and processing ways of the case study method implementation are specified for further development of academic skills of students.

While the advantages of employing case-study method have been noticed and paid much attention to, there is merely a very short study that particularly refers to the practices of casestudy based development of professional communicative competence of the agricultural and environmental engineering students.

\section{Materials and Methods}

The present research is a synthesis of findings from the data collected both at JSC Apatit, one of the world's largest manufactures of phosphate raw materials for the production of mineral fertilizers in Europe and at the Saint-Petersburg Mining University, the first institution of higher technical education in the Russian Federation.

The methodology includes examining of the cases of the ESP course material presenting to engage students with the content of study. The research consists of needs analysis and case-studies. Firstly, needs analysis determining which students' language skills require further development was carried out. In order to identify the English language priorities of the students, a survey was conducted at the Saint-Petersburg Mining University. More than 236 agricultural and environmental engineering students volunteered to take part in the survey. Being interested in the English language needs of the engineering students, different issues were addressed. To find out students' views about how and where English is learnt and used, reasons for learning English and the implications of this for English language teaching and learning the following questions were asked:

1. Where did you start learning English?

Table 1. Place of commencement of English training.

\begin{tabular}{|c|c|}
\hline Place & Percent \\
\hline at school /college/ university & $78 \%$ \\
\hline in extra classes outside your school/college/university & $19 \%$ \\
\hline self-study & $3 \%$ \\
\hline
\end{tabular}

As a result, the majority of the students polled started learning English as a part of their school/college/university classes, while the remaining $19 \%$ took up English in extra classes outside. And only $3 \%$ of the students studied English on their own.

2. How old were you when you started learning English (either at school / university or on your own)? 
Table 2. Age of commencement of English training.

\begin{tabular}{|c|c|}
\hline Age & Percent \\
\hline $0-7$ & $32 \%$ \\
\hline $8-17$ & $55 \%$ \\
\hline $18-25+$ & $13 \%$ \\
\hline
\end{tabular}

In most cases the students were under 18 years of age. The minority tended to be 18 years old or more.

3. What is your English language level?

Table 3. Level of English.

\begin{tabular}{|c|c|}
\hline Level of foreign language proficiency & Percent \\
\hline beginners / elementary & $53 \%$ \\
\hline pre intermediate / intermediate & $30 \%$ \\
\hline upper intermediate / advanced & $17 \%$ \\
\hline
\end{tabular}

Analysing the answers given to the question above, in which the respondents are asked to evaluate their knowledge of English, we can see that only $17 \%$ of that polled think they have a high level of English language proficiency. 30\% say their level is an intermediate or pre intermediate one, and the remaining $53 \%$ admit being beginners.

4. Tick one box for each statement in the list about the English language knowledge and skills you may need.

Table 4. English language skills required.

\begin{tabular}{|l|l|l|l|}
\hline & Agree & $\begin{array}{c}\text { Neither agree } \\
\text { nor disagree }\end{array}$ & Disagree \\
\hline $\begin{array}{l}\text { I need to be familiar with words and expressions in } \\
\text { spoken English }\end{array}$ & & & \\
\hline I need to know grammar & & & \\
\hline I need to have good pronunciation & & & \\
\hline I need to be able to use English in written communication & & & \\
\hline I need to be able to use English in spoken communication & & & \\
\hline I want to learn more about English-speaking countries & & & \\
\hline
\end{tabular}

This section of the questionnaire is concerned with the students' views about their use of English. $50 \%$ of students say they expect to have productive skills. For the remaining respondents English will be used as the medium of instructions for business purposes.

5. Which variety of English do you need to learn?

Table 5. Variety of English.

\begin{tabular}{|l|c|}
\hline \multicolumn{1}{|c|}{ English course } & Percent \\
\hline English related to a specific job or career & $53 \%$ \\
\hline English for Academic Purposes because you are going to study / do research abroad & $40 \%$ \\
\hline $\begin{array}{l}\text { English for General Purposes just for self-development, for reading books in } \\
\text { English, etc. }\end{array}$ & $7 \%$ \\
\hline
\end{tabular}

As it might be expected, English for specific purposes is far more popular nowadays than other courses. Of the 90 students interviewed, the greatest number emphasises the importance of ESP. In addition, the second most popular course, attracting $40 \%$ of students, is English for Academic Purposes.

6. In your opinion, where will you use English most often? 
Table 6. Usage of English.

\begin{tabular}{|l|c|}
\hline \multicolumn{1}{|c|}{ Usage of English } & Percent \\
\hline communication for leisure (social nets, on-line games, face-to-face, etc.) & $53 \%$ \\
\hline as a regular part of your job & $40 \%$ \\
\hline visiting or living in an English-speaking country & $7 \%$ \\
\hline
\end{tabular}

While the Mining University has got the greatest number of students who is going to use English as a regular part of their job - just under 50\% state that they enjoy speaking English in their spare time. Face-to-face communication, on the other hand, is almost as popular as visiting or living in English-speaking countries.

7. Here is a list of possible reasons why students might want to learn English. How important is each reason for you? (Select one box for each reason)

Table 7. Reasons for learning English.

\begin{tabular}{|c|l|l|l|}
\hline & $\begin{array}{c}\text { Very } \\
\text { important }\end{array}$ & Important & $\begin{array}{c}\text { Not at all } \\
\text { important }\end{array}$ \\
\hline $\begin{array}{c}\text { For your future career (to get a good job in your } \\
\text { home country) }\end{array}$ & & & \\
\hline $\begin{array}{c}\text { For your future career (to find work abroad) } \\
\text { To take any international English language } \\
\text { qualification exams }\end{array}$ & & & \\
\hline For travelling & & & \\
\hline To communicate with people who speak English too & & & \\
\hline To understand English language films and songs & & & \\
\hline To appear more intelligent & & & \\
\hline To read authentic articles / books in English & & & \\
\hline For educational purposes & & & \\
\hline
\end{tabular}

This section of the questionnaire focuses on why agricultural and environmental engineering students learn English and the ways of using it. Perhaps surprisingly, almost 60\% of students answer that they enjoy speaking English with native speakers or those who learn or know this foreign language too. Travelling is relatively less popular amongst the reasons, although it still attracts $35 \%$ of the students.

8. To what extent do you agree or disagree with the following statements (tick one box for each statement)

Table 8. ESP course attitude.

\begin{tabular}{|l|l|l|l|}
\hline & Agree & $\begin{array}{c}\text { Neither agree } \\
\text { nor disagree }\end{array}$ & Disagree \\
\hline $\begin{array}{l}\text { In the future, knowing English will be as } \\
\text { important as knowing your mother tongue }\end{array}$ & & & \\
\hline $\begin{array}{l}\text { The English language is a threat to national } \\
\text { languages }\end{array}$ & & & \\
\hline The English language is a key to success & & & \\
\hline
\end{tabular}

This section of the questionnaire focuses on how using English might affect learners' sense of identity. Nearly 40 per cent of the answers state that English is becoming as important as students' native language. Thus, the results obtained by this questionnaire provide clear evidence that students recognise the continuing need to enhance English language proficiency for their future employment and further study.

9. Are you satisfied with the approaches of learning foreign languages offered at your university? If not, briefly state why below. 
Table 9. Students' expectations.

\begin{tabular}{|c|c|}
\hline Attitude & Percent \\
\hline like & $47 \%$ \\
\hline don't like & $47 \%$ \\
\hline don't know & $6 \%$ \\
\hline
\end{tabular}

It is clear from the responses received that the number of students satisfied with teaching techniques is $47 \%$ of all surveyed. One aspect, which strongly draws our attention, is that almost $50 \%$ of students asked feel that they don't like the English language course offered at their university.

The second part of the research contained an experiment that would test students' records and motivation by assigning one group to the treatment conditions in which they were taught using the case study method and others to the conditions in which their study was based on some traditional methods. An experiment was an attempt to monitor changes if any would occur when such a teaching technology was implemented. 88 second year agricultural and environmental engineering students volunteering to participate were randomly assigned to the treatment and control groups in half. These assignments were permanent for the duration of the three-year project. The material to be learnt was the same.

Table 10. Case study organizational structure.

\begin{tabular}{|c|c|c|}
\hline Pre-activity stage & During-activity stage & Conclusion stage \\
\hline situation analysis, & detailed situation analysis in & making the best decision, \\
preliminary investigation, & each group, planning an & constructive feedback, \\
delivering speeches by & effective presentation, group & participants and teacher's \\
participants, teacher's & discussion activity, decision & feedback assessment of \\
feedback, creating groups, & making process, comparing & group work \\
choosing chairmen. & different solutions, activity & \\
& monitoring, presentations of & \\
chairmen & \\
\hline
\end{tabular}

A case study analysis was based on real cases from JSC Apatit, that had been chosen as a research center on the basis of having corporate social responsibility. The company's strategy is to create and develop environmentally friendly business that complies with the highest possible level of profitability and delivers the best quality products.

The first case deals with the carriage of goods by railway. It proposes training students in scientific principles and methods of selecting the most suitable transport mode for the transportation of finished products in agriculture and industry. It illuminates the following dilemma. Alumina, cement, sodium carbonate and tartar salt are produced from apatitenepheline ore apart from mineral fertilizers at the complex of enterprises. The processing of ore and obtaining of apatite and nepheline concentrates are carried out at the ore treatment factory. Nowadays there is an acute problem of transportation costs escalation. Being a transport monopoly, the railways association has increased prices for its services by $15 \%$. Without the shield of price controls carriage costs changes have a direct impact both on the movement of goods and their financial value.

The following tasks were given. Write the list of potential problems for retailers entering market and suggest ways to overcome these challenges.

The second case study comprises the activity of the company and its response to the project of the plant modernizing. The single production complex «Pikalyovo Alumina Refinery» situated in the Leningrad region of the Russian Federation is the only production facility in the world which uses wastes from processing apatite and nepheline ores as raw materials. It consists of three main enterprises: CJSC «BaselCement - Pikalevo» and other key plants «Pikalevo - cement» producing cement and «Metakhim» manufacturing sodium carbonate as well as tartar salt. The refinery raw material base is suitable for production of 
high-quality cement. This company is known to be zero waste one because all three enterprises operate in a closed cycle. The disintegration of the single production complex «Pikalyovo Alumina Refinery» has led to some marketing problems of «BaselCement Pikalevo» and the plant producing sodium carbonate since the cement plant has stopped using as much sludge as it used to buy before. Furthermore, it has demanded reduction of the purchase prices. On account of decreasing of both sludge distribution and its prices the alumina production has become unprofitable. Consequently, separation of the cement plant has resulted in a few difficulties that CJSC «BaselCement - Pikalevo» needs to overcome.

The following questions were asked. Do you think this is a good company to work for? Are there any ways of making alumina production more profitable? Do you think disintegration was a mistake? What are the dos and don'ts of operating in a closed cycle? What can be done to avoid problems?

This case provokes conflicts and forces decision making. Students discuss real business situations in an artificially created professional environment.

While presenting of the third case the following authentic situation is given. According to local media reports JSC Apatit has filed an appeal against the decision by the Moscow Arbitration Court to raise $111 \mathrm{~m}$ rubles for losses filed by the equipment manufacturer. The latter wants to have a bargain by forcing the company to sell their production at lower prices. The Moscow Arbitration Court has approved manufacturer's claim.

The following questions were addressed. Do you think the method used is acceptable? Do you think this is good subsidiary care? Give reasons.

At the end of the course, two types of measurements were used: an achievement test (final exam scores) and a five-point Likert Scale.

\section{Results}

Analysis of the results showed that the ESP teacher's class scored higher in every aspect of the final achievement test, and that they expressed greater satisfaction with the class than the competing class on the Likert Scale. In an effort to assess the impact of case study method on students' performance the following data have been collected.

Table 11. Students' exam results.

\begin{tabular}{|c|c|c|}
\hline & Control group & Treatment group \\
\hline Listening & 4.5 & 6.5 \\
\hline Speaking & 6 & 7,5 \\
\hline Writing & 5 & 6 \\
\hline Reading & 6 & 8 \\
\hline
\end{tabular}

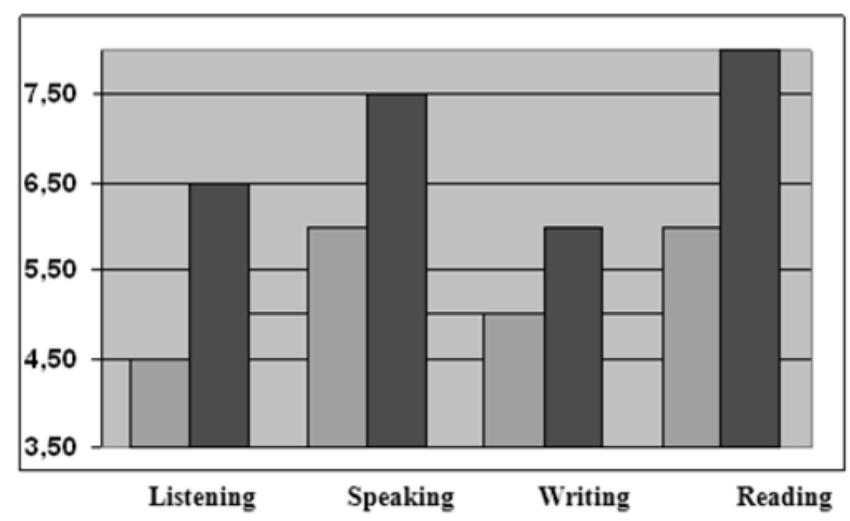

Fig. 1. Students' exam results. 
In other words, the present research has supported the hypothesis that the agricultural and environmental engineering students' professional communicative competence is developed more effectively if different components of teaching are brought together: foreign language skills, e.g. persuasive speaking and some professional aspects of engineering.

As it turns out, more and more learners are looking for relevant feedback about what is going on in industry and agriculture. The students who were in the treatment group expressed much greater satisfaction with their English course than the control group students on the Likert Scale. The following figure illustrates the difference between students' attitude toward English studies in the treatment and control groups.
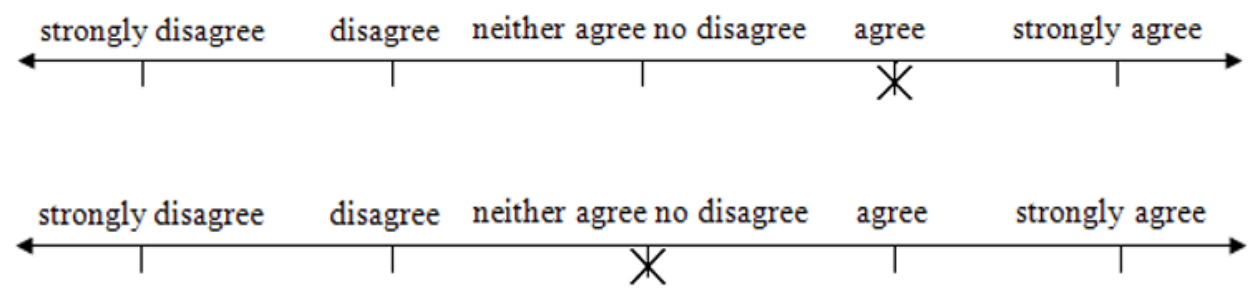

Fig. 2. Attitude of students to English learning.

It can be concluded that in most cases treatment group students were satisfied with the approaches of learning foreign languages offered at university whereas control group students were not completely sure about their choice.

Findings from this study indicate that professional communicative competence is best developed in the context of activities where foreign language is used in practical application. The agricultural and environmental engineering students are interested in consideration search for the best solution and criteria-based assessment because they are able to apply what has been learnt within the agricultural and environmental engineering fields and use this knowledge right away in the classroom artificially created working environment. Using the case-study method enables students to look at a particular professional problem from various perspectives.

\section{Discussion}

Our research on the employment of case-study method of the development of professional communicative competence of agricultural and environmental engineering students confirms the findings of other scientists regarding the advantages of this method employment within ESP [31, 32]. From the perspective of the Russian and foreign researchers within ESP, most students show positive perception of case study as a teaching method because it gives good examples embedded in a broader understanding of what happens in work environments under real circumstances.

The case study-based technology allows academic teaching staff not only to design and follow a syllabus but also to enhance motivation of the future specialists in the fields of agriculture and environmental engineering to foreign language learning by giving them opportunities for further self-development and self - education.

Some researchers emphasize that presenting the case for considering it is important to focus on some issues that arouse the students' interest and capture challenges to address them comprehensively [33].

Thus, the case-study method is viewed to be essential one by the world-wide and Russian scientists especially when students are going to pursue a career in engineering. Further studies to identify the enormous potential of the case study method as well as some broad trends and 
tendencies of engineering students' professional communicative competence development would be of interest.

\section{Conclusion}

All in all, we may conclude that the case-study method is one of the most effective ways to develop professional communicative competence of agriculture and environmental engineering students because it combines foreign language teaching and the subject matter. To reach different goals academic teaching staff can tailor situations to their students' specific needs. Consequently, it is a mutual process as the students with reference to their future occupation are able to apply what they have learnt within ESP to their professional field as well as students' abilities in their subject matter in turn improve their skills and motivate them to learn English.

\section{References}

1. T. Dudley-Evans, M.St. John, Developments in English for specific purposes: a multidisciplinary approach (Cambridge university press, Cambridge, 1998)

2. T. Orr, English for specific purposes (Alexandria, VA TESOL Siegel, 2002)

3. N. Bruce, English for Specific Purposes 21, 321-346 (2002)

4. L.A. Arasaratnam, J. of Inter.and Interc. Com. 8, 290-310 (2015)

5. A.L. George, A. Bennett, Case studies and theory development in the social sciences (MA MIT Press, Cambridge, 2005)

6. A. Strauss., J. Corbin, Grounded Theory Methodology (Cambridge university press, Cambridge, 1994)

7. J. Dul, T. Hak, Case Study Methodology in Business Research. Kindle Edition (2007)

8. M. Burawoy, The Extended Case Method: Four Countries, Four Decades, Four Great Transformations, and One Theoretical Tradition (University of California Press, Berkeley, 2009) http://bookre.org/reader?file=1306800\&pg=2

9. M. Addis, C. Winch, Education and Expertise (Wiley, New York, 2018)

10. S.B. Merriam, Qualitative research and case study applications in education (JosseyBass, San Francisco, 1998)

11. R.K. Yin, Administrative Science Quarterly 26(1), 58-65 (1981)

12. R.K. Yin, Case study research: Design and methods (Sage, Thousand Oaks, CA,1994)

13. R.K. Yin, Health Services Research 34(5), 1209-1224 (1999)

14. R.K. Yin, Case study research: Design and methods (Sage, 2 Thousand Oaks, CA,003)

15. R.K. Yin, Introducing the world of education: A case study reader (Sage, Thousand Oaks, CA, 2005)

16. R.K. Yin, Case study research: Design and methods (Sage, Thousand Oaks, CA, 2009)

17. R.K. Yin, Case study research: Design and methods (Sage, Thousand Oaks, CA, 2015)

18. R.E. Stake, Case studies. In N. K. Denzin, \& Y.S Lincoln (Eds.). Handbook of Qualitative research (Sage Publications, London, 1994)

19. R.E. Stake, The art of case study research (Sage Publications, Thousand Oaks, CA, 1995)

20. R.E. Stake, Case studies (Sage Publications, Thousand Oaks, CA, 2000) 
21. R.E. Stake, Qualitative case studies (Sage Publications, Thousand Oaks, CA, 2005)

22. R.E. Stake, Qualitative case studies (Sage Publications, Los Angeles, 2008)

23. P. Daly, The Internet TESL Journal 15(2), 370-388 (2002)

24. M. Alsawalha, American Journal of Educational Research (Am. J. of Educ. Res) 6(2), 117-122 (2018)

25. N.D. Galskova, E.G. Tsareva, Foreign languages at school (For. lang. at sch.) 1, 3-11 (2012)

26. A.A. Lapinskas, Journal of Mining Institute (JMU) 233, 561-570 (2018)

27. O.I. Kazanin, K. Drebenstedt, Journal of Mining Institute (JMU) 225, 369-375 (2017) doi: 10.18454/PMI.2017.3.369

28. O.P. Kazakova, A.M. Klyoster, Educational tasks modelling on the basis of the webquest technology (from the experience of teaching foreign languages (Astra Salvensis, 2018)

29. M.V. Kuimova, D.E. Evdokimov, K.V. Fedorov, Philological sciences. Issues of theory and practice 3(21), 88-90 (2013)

30. O.V. Sumtsova, T.Y. Aikina, L.M. Bolsunovskaya, O.M. Zubkova, P.J. Mitchell, Inter. J. of Em. Techn in Learn. 13(1), 160-177 (2018)

31. J. Alderson, J. Charles, The Politics of Language Education. Individuals and Institutions (Multilingual Matters, Bristol, 2009)

32. J. Dul, T. Hak, Case Study Methodology in Business Research (Kindle Edition, 2007)

33. C. Winch, Journal of Philosophy of Education 51(3), 673- 688 (2017) 